\title{
How Can Support From Fathers Increase Breastfeeding in Children?
}

\author{
Heni Purwaningsih"1,*, Nurul Azizah², Rosalina Rosalina², and Sri Mintarsih ${ }^{1}$ \\ ${ }^{1}$ Faculty of Health Science, Institute Technology and Science Muhammadiyah Surakarta, \\ Indonesia \\ ${ }^{2}$ Faculty of Health Science, University of Ngudi Waluyo, Semarang, Indonesia \\ ORCID
}

Heni Purwaningsih: https://orcid.org/0000-0001-6973-3163

Corresponding Author: Heni

Purwaningsih; email:

henipurwaningsih@itspku.ac.id

Published: 7 February 2022

Publishing services provided by

Knowledge

(c) Heni Purwaningsih et al. This article is distributed under the terms of the

Attribution License, which

permits unrestricted use and redistribution provided that the original author and source are credited.

Selection and Peer-review unde the responsibility of the IVCN Conference Committee.
G OPEN ACCESS
Abstract. A father who provides full support to his wife in the breastfeeding process, from the phase of pregnancy onwards, can improve breastfeeding. The purpose of this research was to determine the correlation between the breastfeeding support of fathers and the provision of breastfeeding in children aged 6-24 months. This research used a descriptive correlation approach with a cross-sectional design. The sample included 117 respondents, recruited through purposive sampling. Data collection was through a questionnaire and checklist. Analysis of these data was through the Chi-square test. The results of the study showed that 76 respondents (65.0\%) had implemented breastfeeding support by the fathers, and 50 respondents $(42.7 \%)$ carried out partial breastfeeding. The results of the Chi-square test were significant $(p=0.001)$ indicating that there was a correlation between breastfeeding support from fathers and the administration of breastfeeding in children aged 6-24 months. It is therefore suggested that parents who have children aged 6-24 months ensure that the father provides support for breastfeeding for more than 6 months.

Keywords: breastfeeding, father, administening breastfeeding, children

\section{Introduction}

In recent years closer attention has been paid to the role of fathers in both the decision about whether to breastfeed and in supporting a breastfeeding mother [1]. Based on data [2] babies who get breast milk for up to 6 months in each year are decreasing and upgrading. In the year 2011 as much as 34.40\%, the year 2012 increased to 36.44\%, while the year 2013 decreased to 36.29\%, the year 2014 increased to 2016 by $49.34 \%$.

Willingness to breastfeed and successfully carry out is multifactorial. Reviews indicate that effective strategies include close mother-baby skin contact, pumping breast milk, as well as educational efforts to improve the mothers' and medical staff's knowledge regarding breast feeding. Baby-friendly accreditation strongly influences breastfeeding effectiveness in infants in neonatal care units [3]. Mothers who have a partner who is supportive and encouraging are more likely to plan to breastfeed, breastfeed on 
discharge from hospital and to breastfeed for a longer duration. Specifically, higher levels of paternal support and encouragement are associated with greater maternal confidence to breastfeed and mothers whose partner is supportive report feeling more capable and competent in breastfeeding decisions and challenges [4].Breastfeeding father is the full support of a husband to his wife in the breastfeeding process, husband's support in the form of encouraging wives to give breast milk up to 6 months or more, giving a massage on the back of the wife, bathing the baby, replacing Baby Diapers and others [5].

The effort of breastfeeding father implementation begins at the beginning of pregnant women, giving birth until the age of infants aged 2 years. Application at the time of pregnancy aims to build motivation through the knowledge, know the importance of breastfeeding or support, advocator, build atmosphere, help solve the problem, and choose maternity home for babies, after childbirth aims to accompany the wife in the maternity room, help the wife to get comfort or a comfortable position, the wife feel relaxed and calm, husband need to know the importance of breastfeeding, help affairs and homework, show love Affection and empathy, accompany nursing mothers even at midnight and assist in treating infants [6].

\section{Methods and Equipment}

This research was descriptive correlation study with a cross sectional design. The population in this research were parent who had children aged 6-24 months in east Ungaran, Semarang Regency, Indonesia. The sample was taken by purposive sampling technique with total sample of 117 parent. This study conducted in April 2019. The independent variables in this research was breastfeeding father and the dependent variable was administering breastfeeding. The data collection in this research was carried out by questionnaire to obtain the primary data directly from respondents related to the variables studied.

The breastfeeding father questionnaire uses 19 statement items consisting of 4 answer choices. If the respondent answered "always" then it was given a score of 4, "often" was given a score of 3 , "sometimes" was given a score of 2 , and if the respondent answered "never" then it was given a score of 1. For a minimum score is 19 and a maximum value of 76 . Good category with score more than 38 and less from 38 is no good category.

Measurement of breastfeeding practice by using a checklist that consists of 3 statements. If the respondent answers that his child is always given breast milk without mixing 
TABLE 1: An overview of respondent's number of child, gender of child, parent education, parent occupation, breastfeeding father and administering brestfeeding

\begin{tabular}{|c|c|c|c|}
\hline Variable & Category & Frekuensi (n) & $\%$ \\
\hline $\begin{array}{l}\text { Number of } \\
\text { child }\end{array}$ & $12>2$ & 475317 & $\begin{array}{l}40.2 \\
45.3 \\
14.5\end{array}$ \\
\hline $\begin{array}{l}\text { Gender } \\
\text { child }\end{array}$ & Boy Girl & 7641 & $\begin{array}{l}65.0 \\
35.0\end{array}$ \\
\hline $\begin{array}{l}\text { Fathers } \\
\text { education }\end{array}$ & $\begin{array}{l}\text { Junior high school Senior high school } \\
\text { University }\end{array}$ & 55953 & $\begin{array}{l}4.3 \\
50.4 \\
45.3\end{array}$ \\
\hline $\begin{array}{l}\text { Mothers } \\
\text { education }\end{array}$ & $\begin{array}{l}\text { Junior high school Senior high school } \\
\text { University }\end{array}$ & 45251 & $\begin{array}{l}3.4 \\
44.4 \\
43.6\end{array}$ \\
\hline $\begin{array}{l}\text { Parent } \\
\text { occupation } \\
\text { (father) }\end{array}$ & Employee Unemployee & 1170 & $\begin{array}{l}100.0 \\
0.0\end{array}$ \\
\hline $\begin{array}{l}\text { Parent } \\
\text { occupation } \\
\text { (mother) }\end{array}$ & Employee Unemployee & 6651 & $\begin{array}{l}56.4 \\
43.6\end{array}$ \\
\hline $\begin{array}{l}\text { Breastfeeding } \\
\text { father }\end{array}$ & Not Good Good & 4176 & $\begin{array}{l}35.0 \\
65.0\end{array}$ \\
\hline $\begin{array}{l}\text { Administering } \\
\text { breastfeeding }\end{array}$ & $\begin{array}{lr}\text { Partial breastfeeding } & \text { Predominant } \\
\text { breastfeeding } & \text { Eksklusif } \\
\text { breastfeeding } & \end{array}$ & 502542 & $\begin{array}{l}42.7 \\
21.4 \\
35.9\end{array}$ \\
\hline
\end{tabular}

anything except drugs and vitamins, the result is number is exclusive breastfeeding category, if the respondent given breastfed but mixed with water or tea is predominant breast milk category and the respondent given breast milk also been given formula milk, porridge, etc., is partial breast milk category.

After all the data were collected, data analysis was carried out in the form of univariate analysis and bivariate analysis to determine the relationship between father breastfeeding and administering breastfeeding in children.

\section{Result}

\subsection{An overview of respondent's number of child, gender of child, parent education, parent occupation, breastfeeding father and administering brestfeeding}

Based on table 1 The majority of respondents had a second child (45.3\%) and only (14.5\%) of responden who had childrens more than two. More than half their childrens were a boy (65\%). Most of father and mother education were senior high school (50.45) 
TABLE 2: The relationship between Breastfeeding father and administering breastfeeding in children

\begin{tabular}{|c|c|c|c|c|c|c|c|c|c|}
\hline \multirow{3}{*}{$\begin{array}{l}\text { Breastfeeding } \\
\text { father }\end{array}$} & \multicolumn{8}{|c|}{ Administering Breastfeeding } & \multirow{3}{*}{$\begin{array}{l}\text { Chi } \\
\text { Square } \\
p \text { - } \\
\text { value }\end{array}$} \\
\hline & \multicolumn{2}{|c|}{$\begin{array}{l}\text { Breastfeeding Par- } \\
\text { sial }\end{array}$} & \multicolumn{2}{|c|}{$\begin{array}{l}\text { Breastfeeding Pre- } \\
\text { dominan }\end{array}$} & \multicolumn{2}{|c|}{$\begin{array}{l}\text { Breastfeeding } \\
\text { Eksklusif }\end{array}$} & \multicolumn{2}{|c|}{ Total } & \\
\hline & $\mathrm{F}$ & $\%$ & $\mathrm{~F}$ & $\%$ & $\mathrm{~F}$ & $\%$ & $\mathrm{~F}$ & $\%$ & \\
\hline Kurang Baik & 2525 & 61.032 .9 & 1015 & 24.419 .7 & 636 & 14.647 .4 & 4176 & $\begin{array}{l}35.0 \\
65.0\end{array}$ & 0,001 \\
\hline Total & 50 & 42.7 & 25 & 21.4 & 42 & 35.9 & 117 & 100 & \\
\hline
\end{tabular}

for father and (44.4\%) for mother education. All of father were employee (100\%) and most of mother were employee with total 66 mothers (56.4\%).

In breastfeeding father variable 76 respondents (65.0\%) had good in breastfeeding father and 35 respondents (35.0\%) had not good in breastfeeding father implementation. In the variable of administering breastfeeding as many as 50 mother (42.7\%) had partial breastfeeding, predominant breastfeeding were 25 (21.4\%) and exclusive breasrfeeding 42 (35.9\%).

\subsection{Analysis of relationship between breastfeeding father and administering breastfeeding in children}

Based on table 2 shows that the result of the bivariate analysis test of the correlationship between breastfeeding father and administering breastfeeding in children using the chi-square test obtained a significance value of $0.001<0.05$ so that it can be conclude that there is significant relationship between father breastfeeding with administering breastfeeding in children.

\section{Discussion}

\subsection{Analysis breastfeeding father and administering breastfeeding in children}

The results of this study were found that most husbands played a good role in the implementation of the breastfeeding father, which is 76 respondents (65.0\%). Some fathers associate maternal breastfeeding with feelings of exclusion from the motherinfant relationship and with negatively affecting father-infant bonding. In the past, breastfeeding has been identified as a negative paternal risk factor for father-infant bonding and the marital relationship [6]. Other fathers described breastfeeding as 
having a positive impact, reporting their partners were better and more quickly able to regain their prepregnancy body shape others indicated that they found the larger size of their partners' breasts attractive [1]. Fathers in a U.S. study felt that concerns based on body image should not affect the decision to breastfeed and that stopping breastfeeding should not occur just because women don't want their boobs to sag [7]. Partner support is provided in a responsive manner as part of a breastfeeding team, thereby promoting the woman's sense of autonomy and self-efficacy, breastfeeding outcomes improve [8]Supportive behaviours were categorized as knowledge, help, encouragement and responsiveness. Help and encouragement behaviours were associated with increased initiation. Results were mixed regarding behaviours affecting exclusivity and duration; however, responsiveness was found to ameliorate otherwise generally negative effects of knowledge, help, and encouragement on these outcomes.[8]

The results obtained that the most of the administering breastfeeding was $42.7 \%$ predominant breastfeeding category. According to [9] 23.2\% of infants were exclusively breastfed until 6 months, with 28.2\% predominantly breastfed and 48.6\% partially breastfeeding. Predominant breastfeeding refers to breast milk used as a predominant source of nourishment. It can include water and water-based drinks, fruit juice, ritual fluids, and medicines. According to [5] there is a relationship between the level of education and exclusive breastfeeding at the Pulau Panggung Health Center. Education is related a person's ability to learn behaviors, low level of education will hinder a person's development and attitude towards the newly introduced values [10].

According study in a community-based study in Bhaktapur, Nepal, working mother was associated with poorer breastfeeding practices[3]. This study show that 66 mother (56.4\%) mother was employee. That is because mother was busy working and no more time to breastfeed. Mother who has employee prefer to give formula milk as a substitute for breast milk to make it more practical [11].

Based on table 1 show that most of parent have 2 child 53 respondent $(45,3)$ its means that parents have an experience in breastfeeding. According to [11] that experience gained as well as environmental factors will affect the mother's knowledge and finally can form a response of behavior to give breast milk. Experience can be used as a source of knowledge for the present. Previous breastfeeding experience determines the decision to breastfeed. Breastfeeding experience has a positive relationship between the duration of breastfeeding in the previous child, especially the child right before the current child and breastfeeding in the current child. Breastfeeding experience in primiparity women plays an important role in breastfeeding the next child[11][5]. 


\subsection{The relationship between breastfeeding father with adminis- tering breastfeeding in children}

Based on the result there was a significant correlation between the breastfeeding father and administering breastfeeding in children. According to [1] a significant relationship between the breastfeeding father with the decision of mothers to perform exclusive breast milk. Breastfeeding father will help the wife in success in the provision of breast milk twice more than the mother who does not get support from husbands [12].

This research demonstrates that fatherbreastfeeding can have a considerable influence on a mother's decision to initiate and continue with breastfeeding. Therefore, meaningful involvement and engagement with men and fathers by health practitioners may augment existing service provision for breastfeeding mothers. Indeed, we have proposed that fathers have an important but overlooked role in supporting their breastfeeding partner, and express concern that the practice of providing effective support to fathers in their parenting role continues to lag behind policy aspirations considerably[13]. It is important to understand more fully the role of a father's support in the breastfeeding process as it is, arguably, unlikely that any intervention designed to increase rates of breast feeding will be successful without taking this into account. This is particularly important when trying to address inequalities between different socio-economic groups.

The role of a partner is very important in helping mothers deal with problems that may arise. Breastfeeding father can help mothers, especially in their coping, in dealing with stress that may arise when breastfeeding. Breastfeeding mothers should of course be in a calm state and a happy mood. Stressed mothers will cause disturbances in their milk production which will affect the ongoing breastfeeding process. Breastfeeding father is needed to make mothers happy and not stressed. Breastfeeding father include financially, emotionally and physically, this does not affect the mother in breastfeeding. This may be since all three forms of support must be given simultaneously to significantly influence the mother's breastfeeding process [14].

A husband plays an important role in making decisions about family, household problems and influencing many aspects of family life including the practice of feeding infants. Therefore, husband's support is one of the factors determining the opportunity of mothers to practice breastfeeding exclusively. Lack of support for mothers to breastfeed can affect mothers not to breastfeed their babies[15]. 


\section{Conclusion}

Educating healthcare professionals about the importance of engaging fathers during perinatal visits is an important intervention to facilitate the father's support in breastfeeding. Practical information that is "father friendly" was a common request from several studies. Fathers want to be provided with information that is useful and addresses questions regarding how to assist their partner through difficult times. More evidence is needed to validate the effectiveness of peer support groups, classroom led instruction, and educational materials such as books, pamphlets, and posters. Therefore, further studies should be implemented to determine the most effective way to support fathers and provide.

\section{Funding}

None

\section{Acknowledgement}

None

\section{Conflict of Interest}

The authors declare that there is no conflict of interest.

\section{References}

[1] Rempel LA, Rempel JK, Moore K. Relationships between types of father breastfeeding support and breastfeeding outcomes. Maternal \& child nutrition. 2017;13.

[2] Kemenkes RI. Health statistics (health information system). 2019.

[3] Maharlouei N, Pourhaghighi PMD, Amirhosein $\mathrm{H}$, et al. Factors affecting exclusive breastfeeding. International journal of community based nursing and midwifery. 2018;6(3):260-271.

[4] Brown A, Davies R. Fathers' experiences of supporting breastfeeding: Challenges for breastfeeding promotion and education. Maternal \& child nutrition. 2014;10(4):510526. doi: $10.1111 / \mathrm{mcn} .12129$ 
[5] Raj, Francisca J, Fara, et al. Faktor yang mempengaruhi pemberian ASI eksklusif. J. Wellnes. 2020;2:309-313.

[6] Sihota H, Oliffe J, Kelly MT, McCuaig F. Fathers' experiences and perspectives of breastfeeding: A scoping review. American journal of men's health. 2019;13(3). doi: 10.1177/1557988319851616.

[7] Sherriff N, Hall V, Panton C. Engaging and supporting fathers to promote breast feeding: A concept analysis. Midwifery. 2014;30(6):667-677. doi: 10.1016/j.midw.2013.07.014

[8] Mannion CA, Hobbs AJ, McDonald SW, Tough SC. Maternal perceptions of partner support during breastfeeding. International breastfeeding journal. J. 2013;8(1):1-7. doi: 10.1186/1746-4358-8-4

[9] Dharel, D., Dhungana, R., Basnet, S., Gautam, S., Dhungana, A., Dudani, R., \& Bhattarai, A. Breastfeeding practices within the first six months of age in mid-western and eastern regions of Nepal: A health facility-based cross-sectional study. BMC Pregnancy Childbirth. 2020;20(1):1-9. doi: 10.1186/s12884-020-2754-0

[10] Notoatmodjo S. Pendidikan dan perilaku kesehatan. 2012.

[11] Hastuti BW, Machfudz S, Febriani F, Budi T. Pendidikan ibu dengan pemberian asi eksklusif di kelurahan barukan kecamatan manisrenggo kabupaten klaten. Jkki. 2015;6(4):179-187.

[12] Crippa, B. L., Consales, A., Morniroli, D., Lunetto, F., Bettinelli, M. E., Sannino, P., ... \& Colombo, L. From dyad to triad: A survey on fathers' knowledge and attitudes toward breastfeeding. European Journal of Pediatrics. 2021;180(9):2861-2869. doi: 10.1007/s00431-021-04034-x

[13] Sherriff N, Panton C, Hall V. A new model of father support to promote breastfeeding. Community Pract. 2014;87(5):20-24.

[14] Yanti ES, Damayani AD. Father's role on the exclusive breastfeeding. Women, Midwives and Midwifery. 2021;1(1):15-20. doi: 10.36749/wmm.1.1.15-20.2021

[15] Efriani R, Astuti DA. The relationship husband's support and exclusive breastfeeding in the work area of Umbulharjo 1 public health center, Yogyakarta City. International Journal of Health Science and Technology. 2021;2(2):1-7. doi: 10.31101/ijhst.v2i2.1836 